\title{
Frequency-dependence of Mating Success in Poeciliopsis monacha (Pisces, Cyprinodontiformes) Reproductive Complex, Sonora, Mexico
}

\author{
Neuza Rejane Wille Lima ${ }^{1 *}$ and Carlos Roberto S. F. Bizerril ${ }^{2}$ \\ ${ }^{1}$ Universidade Federal Fluminense (UFF); Laboratório de Genética Evolutiva de Peixes. ${ }^{2}$ Universidade do Rio de \\ Janeiro (UNIRIO); Laboratório de Avaliação Ambiental
}

\begin{abstract}
A diversity of all-female fishes of the genus Poeciliopsis coexists with their sexual ancestor species in streams of western Mexico. All-females are hybrids that depend on the sperm of paternal species to reproduce. Rare-female advantage is one of several hypotheses that attempt to explain how the diversity of all-female biotypes is maintained within the Poeciliopsis reproductive complexes. According to this hypothesis, the uncommon all-female biotype has a mating advantage over the common ones and has been maintained by a dynamic equilibrium process. In the P. monacha reproductive complex at Arroyo de los Platanos the density of two all-female biotypes (P. 2 monacha-lucida I and II) varies across pools. The objective of this study was to analyse fecundity and mating success of females from this arroyo to test the hypothesis. Female mating success was inversely correlated to their density, supporting this hypothesis.
\end{abstract}

Key words: All-females, mating success, Poeciliopsis monacha, rare-female advantage

\section{INTRODUCTION}

Natural all-female biotypes (unisexual forms) are rare among vertebrates and usually involve several ecological restrictions (Vrijenhoek et al., 1989). Unlike truly parthenogenetic lizards, all-female biotypes of fishes, salamanders, and frogs require sperm by males of a closely related sexual species to reproduce. Such sexual parasitism implies a strong competition for sperm, food, and space among members of reproductive complexes (Schenck \& Vrijenhoek, 1986; Schenck \& Vrijenhoek, 1989; Vrijenhoek et al., 1989; Weeks et al., 1992).

A paradoxical coexistence among all-female biotypes and the sexual species exists because the sexual parasite cannot escape or completely replace their host (Schultz, 1967; Vrijenhoek, 1979; Schultz, 1982; Schultz, 1989). The replacement of the sexual species by all-female biotypes would result in the demise of the latter. However reproductive complexes seem to be temporally stable (Stenseth et al., 1985) where sexual species and several all-female biotypes that often successfully co-exist even though strong competition for resources such as sperm, food and space (Schultz, 1969; Vrijenhoek, 1979; Vrijenhoek, 1984a; Vrijenhoek, 1984b; Schenck \& Vrijenhoek 1989; Weeks et al.,1992; Lima et al., 1996).

Reproductive complexes of fishes in the genus Poeciliopsis have been intensively studied to

\footnotetext{
${ }^{*}$ Author for correspondence
} 
understand how the paradoxical coexistence between sexual and all-female biotypes is possible and to identify mechanisms that might sustain a diversity of all-females biotypes (Moore, 1984; Schultz, 1989; Vrijenhoek, 1993).

Basically, one resource partitioning hypothesis (frozen-niche variation) and two behavioural regulation hypotheses (sperm-limited and rare female advantage) attempted to explain the paradoxical coexistence in Poeciliopsis complexes (Moore \& Mckay, 1971; Vrijenhoek 1984a; Keegan-Rogers \& Schultz 1988).

The frozen niche-variation hypothesis proposes that ecologically different all-female biotypes have independent hybrid origins from sexual ancestors that possessed genetic variability for traits affecting niche breadth (Vrijenhoek 1984a; Weeks et al. 1992; Lima \& Vrijenhoek, 1996; Lima, 1998).

Moore \& Mckay (1971) developed the spermlimitation hypothesis based on male sexual behaviour in the Poeciliopsis lucida reproductive complex.

Reproduction of all-females $P$. monacha-lucida is sperm-limited, because $P$. lucida males strongly prefer conspecific sexual females as mates (Mckay, 1971). Within the P. lucida reproductive complex, inseminations of all-female biotypes appear to be a function of the proportion of sexual males in the population (Moore \& Mckay, 1971; Moore, 1976; Moore, 1984). Solitary males prefer conspecific sexual females, but when males are common they establish dominance hierarchies and only subordinate males mate with all-females (Mckay, 1971).

Males of $P$. lucida typically approach females with a series of snout-genital contacts, a form of behaviour that might have to do with species identification (Kennett, 1979). The ability of allfemale specimens to mimic the genital patterns of $P$. lucida females appears to be an important mechanism to compete for sperm (Lima et al., 1996).

Keegan-Rogers \& Schultz (1988) observed that males of $P$. lucida can discriminate against females of the most common all-female biotype and mate with all-females of the rare or novel forms. Therefore they proposed that rare-female advantage might facilitate the natural coexistence of sexual species and all-female biotypes, promoting a diversity of unisexual forms via a dynamic equilibrium.
Rare-female advantage has given rise to frequency-dependent sexual selection when females compete for mates (Mugglenton, 1979; O'Donald \& Mugglenton, 1979). Some field samples in the $P$. lucida reproductive complex, seems to supportthis prediction (Schultz, 1982).

The $P$. monacha complex at Arroyo de los Platanos seems to be a natural model for testing the rare-female advantage hypothesis. In this place, the frequency of two sperm-dependent biotypes of $P$. monacha ( $P$. 2monacha- lucida electromorphs I and II) varies greatly across numerous interconnected small pools in the Arroyo de los Platanos and tributaries (Vrijenhoek, 1979). The purpose of the study was to analyse the reproductive performance of females and to test whether uncommon all-female biotypes have a mating advantage over the common ones.

\section{MATERIAL AND METHODS}

Poeciliopsis is a viviparous fish that stores sperm from multiple inseminations in the folds lining the ovary and gonoduct and has two or three broods at different stages of development within their ovaries (superfetation). Number of embryos reflects the amount of sperm (Turner, 1937; Thibault \& Schultz, 1978). Reproduction in the species $P$. monacha and P. lucida is biparental and involves conventional Mendelian processes (Leslie, 1982). Two different reproductive modes arose as $P$. monacha $\mathrm{x} P$. lucida hybrids hybridogenesis and gynogenesis (Schultz, 1967; Schultz, 1969; Cimino, 1972a; Cimino, 1972b). Only gynogenetic all-female biotypes were analysed in the present study. Gynogenesis is an asexual mode restricted to triploid all-females like P. 2monacha-lucida and $P$. monacha-2lucida (Schultz, 1967). The triploid gynogens, $P$. monacha-2lucida and $P$. 2monacha-lucida produces triploid ova. P. monacha-2lucida, relies on $P$. lucida males for insemination, whereas $P$. 2monacha-lucida depends on $P$. monacha males (Schultz, 1989).

Fish were collected with a minnow seine $(2 \mathrm{~mm}$ mesh) from four natural rock pools in the Arroyo de los Platanos (Río del Fuerte, Sonora, Mexico) in late April, 1987. Natural populations of Poeciliopsis of Mexico typically reproduce from February throughout the summer to late October without any siginicant variation (Thibault \& Schultz 1978). Samples were collected in four 
pools: Log, Sandal, First, and Jaguari, pursuing one transect from up to down stream. A map of the area is provided in Vrijenhoek et al. (1992). Immediately following capture, specimens were frozen on dry-ice and subsequently stored at $70^{\circ} \mathrm{C}$. These samples were previously analysed by Lively et al. (1990) and constituent species and clones were identified by electrophoresis of eye tissue extracts. Four enzyme loci [Ldh-1, Pgd-6, Idh-2, and Ck-3 (= Mp-3)] were used to completely discriminate among the components (strains) of $P$. monacha reproductive complex (Vrijenhoek, 1979). To simplify, the following code was adopted: $P$. 2monacha-lucida electromorph $\mathrm{I}=\mathrm{MML} / \mathrm{I} ;$ P. 2monacha-lucida electromorph II $=\mathrm{MML} / \mathrm{II} ;$ P. monacha $=\mathrm{MM}$. Only mature females (containing at least one mature egg or one embryo) were examined in the present study.

Ovarian contents from 618 females preserved in $70 \%$ ethanol were analysed. Standard lengths were measured as the distance between the tip of the snout and the caudal peduncle. Size and number of mature eggs and the number of embryos were quantified to assess variance in reproductive investment and mating success. Eggs bigger then $1,5 \mathrm{~mm}$ diameter and presenting yellow and opac colour are classify as mature (Quattro \& Vrijenhoek, 1989; Quattro \& Weeks, 1991.In total, the size of 1,110 mature eggs of P. monacha, 377 of MML/I and 206 of MML/II were measured. The diameter of Poeciliopsis eggs predicts their energy content (Quattro \& Weeks, 1991). The maximum and minimum diameters $\left(\mathrm{d}_{\max }\right.$. and $\mathrm{d}_{\text {min. }}$. of each egg were measured to $\pm 0.01 \mathrm{~mm}$ using a dissecting microscope and ocular micrometer. The average between these two measurements $\left(d_{\text {aver }}=\right.$ $\left.\left(\mathrm{d}_{\text {max }} .+\mathrm{d}_{\text {min. }}\right) / 2\right)$ was calculated to assess mean diameter of mature eggs of each specimen.

Fecundity was estimated as the total number of mature eggs plus developing embryos. The presence and quantity of embryos were used to estimate mating success. Mating success among strains was evaluated by assessing the frequency of pregnant females (containing one or more embryos) in each population (Mckay, 1971). Because the number of embryos per strain seems to depend on the amount of sperm (Thibault \& Schultz 1978) and frequency of pregnant females does not account for the difference in standard lengths and fecundity among and within strains (Lima et al., 1996) we also analysed mating success within strains (MSw) as the number of embryos in each female, removing the effects of standard length and the difference in fecundity, following statistical methodology used by Lima et al. (1996).

All analyses were performed using the General Linear Models, Frequency, and Univariate procedures of the SAS statistical package (SAS, 1985). Results of all traits were natural-log transformed and data did not significantly deviate from a normal distribution. Analyses of variance (Type III) of standard length and diameters of mature eggs were performed using pools as covariate.

The relationship between standard lengths and fecundity and between fecundity and embryos were significant $(P \leq 0,05)$. Analyses of variance (ANOVA) of fecundity were performed using standard length and pools as covariates and of the number of mature eggs using standard length, fecundity, and pools as covariates. The differences in size and fecundity among the strains were removed via regression. Number of embryos size and fecundity adjusted was used as mating success estimate (MSw) (Lima et al., 1996). ANOVA was performed on diameter of eggs, fecundity sizeremoved, and mating success to identify the source of variation, using pools as covariate. The least square means of mating success were correlated with the female frequencies across pools using Spearman correlation analysis.

\section{RESULTS}

In total, 618 females were analysed and classified as immature (without eggs and smaller then 16 mm, (Thibault \& Schultz 1978). Only mature females were analysed to test the hyphothesis. The number of MM specimens was larger than the number of specimens of MML/I and MML/II together (Table 1). Populations from First and Sandal pools contained similar proportions of the strains MML/I and MML/II. On other hand, the number of MML/I specimens in the Jaguari pool was lower than the number of MM or MML/II specimens. A different situation was observed in Log pool, where specimens of MML/II were rare in relation to the specimens of MM or MML/I.

The means of egg sizes were not significantly different among pools. Fecundity significantly varied among pools $\left(F_{3,510}=5.46 ; P=0.0011\right)$. Means of fecundity and of number of embryos for 
the strain MM collected at Log pool were higher than for the other three pools due to the body sizes (Table 2). For the strains MML/I and MML/II, the means of fecundity were higher in Jaguari pool, reflecting the body size of specimens.

The overall analysis showed that means size of females significantly varied among pools
$\left(F_{3,510}=7.33 ; P=0.0001\right)$. Females of the strain MM collected in Log pool were significantly larger than the others two strains. The largest specimens of MML/I and MML/II were collected in Jaguari pool. Number of embryos significantly varied among pools $\left(F_{3,510}=14.54 ; P=0.0001\right)$.

Table 1 - Number of females (Nf) and number of mature females (Mf) of the strains Poeciliopsis monacha (MM), Poeciliopsis 2monacha-lucida electromorph I (MML/I) and electromorph II (MML/II) collected in four pools.

\begin{tabular}{ccccccc}
\hline & \multicolumn{3}{c}{ MM } & \multicolumn{2}{c}{ Nf Mf) } & \multicolumn{2}{c}{ MM/II } \\
\hline Pools & 63 & $(61)$ & 74 & $(69)$ & 04 & $(03)$ \\
Sandal & 115 & $(90)$ & 44 & $(40)$ & 66 & $(55)$ \\
First & 96 & $(53)$ & 16 & $(15)$ & 19 & $(16)$ \\
Jaguari & 101 & $(91)$ & 03 & $(03)$ & 17 & $(16)$ \\
\hline
\end{tabular}

Table 2 - Means and minimum and maximum (min. - max.) values of standard size (SL, mm), egg diameter (Egd, $\mathrm{mm}$ ), fecundity (FE), number of embryos (EM), and of the strains Poeciliopsis monacha (MM), Poeciliopsis 2monacha-lucida I (MML/I) and II (MML/II) collected in each pool.

\begin{tabular}{ccccc}
\hline Variables & Pools & MM & MML/I & MML/II \\
\hline SL & Log & $30.35(19.74-41.60)$ & $26.38(19.67-36.57)$ & $29.18(26.74-30.98)$ \\
& Sandal & $26.37(19.35-39.26)$ & $27.78(19.24-34.59)$ & $27.52(19.73-41.16)$ \\
& First & $26.78(19.73-36.16)$ & $23.84(18.68-30.09)$ & $28.94(22.66-39.37)$ \\
& Jaguari & $25.61(18.73-35.30)$ & $35.81(30.39-41.22)$ & $33.00(24.65-39.35)$ \\
EGd & Log & $2.20(1.77-2.47)$ & $1.98(0.00-2.52)$ & $2.21(2.07-2.28)$ \\
& Sandal & $2.08(0.00-2.47)$ & $1.80(0.00-2.44)$ & $1.72(0.00-2.41)$ \\
& First & $2.21(1.84-2.38)$ & $1.95(0.00-2.34)$ & $1.72(0.00-2.38)$ \\
& Jaguari & $1.94(0.00-2.42)$ & $2.20(2.18-2.22)$ & $1.56(0.00-2.26)$ \\
FE & Log & $16.93(2.00-36.0)$ & $6.50(5.00-8.00)$ & $7.67(7.00-9.00)$ \\
& Sandal & $6.54(1.00-34.0)$ & $4.20(1.00-11.0)$ & $3.75(1.00-23.0)$ \\
& First & $7.53(1.00-22.0)$ & $2.53(1.00-6.00)$ & $4.56(1.00-11.0)$ \\
& Jaguari & $4.09(1.00-13.0)$ & $6.77(1.00-26.0)$ & $7.31(1.00-16.0)$ \\
& Log & $10.90(0.00-26.0)$ & $2.61(2.00-3.00)$ & $4.00(2.00-7.00)$ \\
& Sandal & $3.09(0.00-21.0)$ & $2.53(0.00-8.00)$ & $1.55(0.00-10.0)$ \\
& First & $3.74(0.00-16.0)$ & $1.20(0.00-5.00)$ & $2.88(0.00-9.00)$ \\
& Jaguari & $1.55(0.00-7.00)$ & $2.50(0.00-17.0)$ & $4.06(0.00-14.0)$ \\
\hline
\end{tabular}

Table 3 - Least square means of egg diameter (LsEgd), fecundity size-corrected (LsFesz) and mating success (LsMSw) of the strains Poeciliopsis monacha (MM), Poeciliopsis 2monacha-lucida I (MML/I) and II (MML/II), combining females across pools.

\begin{tabular}{cccc}
\hline Variables & MM & MML/I & MML/II \\
\hline LsEGd & 1.11 & $0.92^{\mathrm{a}}$ & $0.99^{\mathrm{a}}$ \\
LsFEsz & 1.82 & $1.07^{\mathrm{b}}$ & $1.27^{\mathrm{b}}$ \\
LsMSw & $0.64^{\mathrm{c}}$ & $0.71^{\mathrm{c}, \mathrm{d}}$ & $0.83^{\mathrm{d}}$ \\
\hline
\end{tabular}

(Least square-means of natural-log transformed data that are not significantly different $(P>0.05)$ were labelled with one or two letters (a-d). According to the Bonferroni inequality, each individual $P$ value was multiplied by the number of variables before to compare it with the overall significance level $\alpha$.) 
On average, mating success of MM females was smaller than all-females. The least-square means of egg diameter were significantly different among strains $\left(F_{2,510}=4.25, P=0.015\right)$. The least-square means of fecundity size-removed were also significantly different among strains $\left(F_{2,} \quad 510=\right.$ $33.58, P=0.001)$.

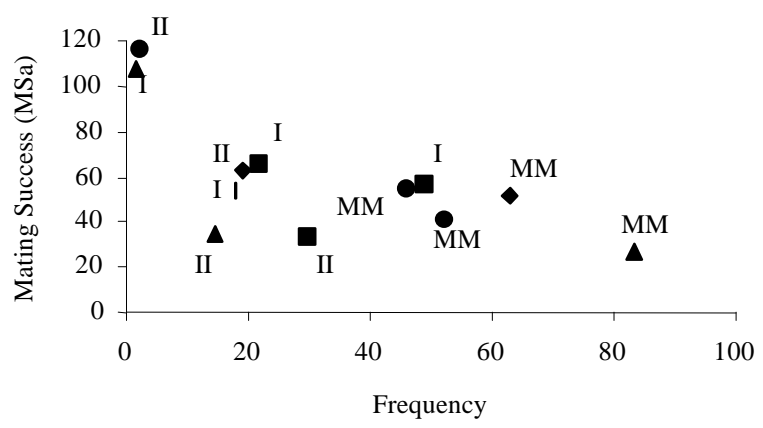

Figure 1 - Relation between the frequency of each strain (FQ) by pool and the estimate of mating success among strains (MSa) as the percent of pregnant females. (Legends - MM: P. monacha; I: MML/I; II: MML/II; $:$ Log pool; $\square$ : Sandal pool; $\bullet:$ First pool, and $\boldsymbol{\Lambda}$ : Jaguari pool).

The results of mating success were significantly different between MM and MML/I (MSw: $F_{2,510}=$ 5.37, $P=0.004$ ) because the large (LsMSw) was affected by the geographic variation when using pools as covariates $\left(F_{4,11}=0.40, P=0.801\right)$. The relation between the two mating success estimates (MSa and LsMSw) and the frequency of females of each strain per pool (FQ) were performed to test the rare-female advantage hypothesis (Figure 1 and 2).

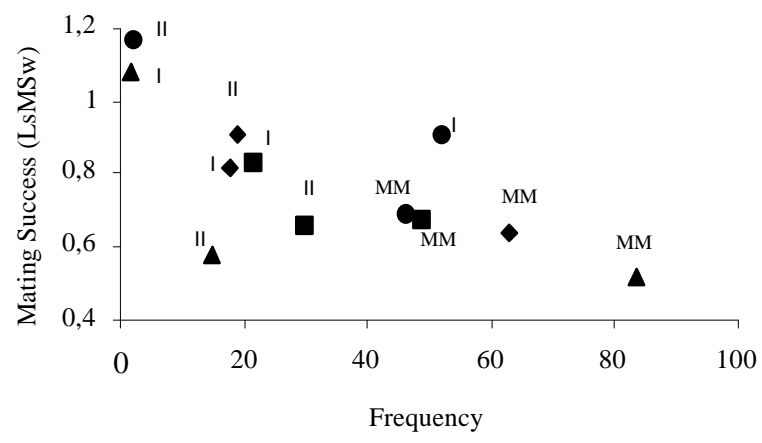

Figure 2 - Relation between the frequency of each strain (FQ) by pool and the estimate of mating success (LsMSw) as the least-square means of number of embryos. (Legends - MM: P. monacha; I: MML/I; II: MML/II; ○: Log pool; $\mathbf{\square}$ : Sandal pool; $\bullet:$ First pool, and $\boldsymbol{\Delta}$ : Jaguari pool).

\section{DISCUSSION}

Fishes from the study area commonly exhibit black spot disease, an infection by trematode larvae (Uvulifer $s p$.) which form externally visible cysts after burrowing into the body wall (Lively, et al. 1990). Parasite load can be related to the variance in reproductive success of animals (Minchella \& Lovede 1981; Hamilton, 1982; Hamilton \& Zuk, 1982; Anderson \& May, 1985; Minchella, 1985; Kennedy et al., 1987; Fryer et al. 1990). However Weeks (1996) showed that fecundity of females were not affected by parasite load.

Significant variances on size of eggs and fecundity were observed among strains. The differences between females of P. monacha and the two allfemale biotypes of $P$. 2monacha-lucida for these traits were expected (Schultz, 1969; Thibault \& Schultz, 1978; Schultz 1982). The hybrids between females of $P$. monacha and males of $P$. lucida (i.e., P. 2monacha-lucida (MML), $P$. monacha-lucida (ML), and P. monacha-2lucida (MLL) exhibited a gradient on reproductive investment that seems to be closely related to parental genomic dosage grade ( $P$. monacha vs. $P$. lucida). Although parental genomic dosage grade account for some of the life-history variation among all-females some differences in reproductive success might take place between biotypes that have the same dosage (i.e., MML/I vs. MML/II) because of their genetic differences (Vrijenhoek, 1984a; Vrijenhoek, 1984b).

Such differences may be one of the mechanisms that maintain the coexistence between the closely related all-females biotypes.

Competitive modes involving resource partitioning and the plasticity of life history, morphological traits and behavioural patterns might circumvent rivalry among members of reproductive complexes. These strategies have been the best explanation for the paradoxical coexistence among sexual and all-female biotypes (Balsano et al., 1981; Vrijenhoek, 1984a; Balsano et al., 1985; Lima et al. 1996; Lima \& Vrijenhoek 1996; Lima 1998).

The present result is the first suitable evidence supporting the hypothesis that rare-female advantage operates in natural populations of Poeciliopsis. An uncommon all-female biotype presented more embryos than the common biotype of next generation. Thus, the rare-female advantage for mates might advance a frequency- 
dependence diversity of all-female biotypes in both $P$. monacha (the present study) and $P$. lucida reproductive complexes (Keegan-Rogers \& Schultz 1988).

The effects of frequency-dependence in sexual selection should generate a dynamic equilibrium among all-female strains preventing extinction of rare clones of all-females, favouring newly arrived clonal forms, and promoting coexistence of multiple clones (Keegan-Rogers \& Schultz 1988).

Results obtained in laboratory from Poeciliopsis lucida and it sperm-dependent all-female biotypes $(P$. monacha-lucida) suggested that the rarefemale advantage operates in the reproductive complex of Poeciliopsis and that such sexual behaviour regulates community structure (Schultz, 1982; Keegan-Rogers \& Schultz, 1988). However, the results from field collection and it might significantly contribute to the recruitment of next generation. Thus, the rare-female advantage for mates might advance a frequency-dependence diversity of all-female biotypes in both $P$. monacha (the present study) and $P$. lucida reproductive complexes (Keegan-Rogers \& Schultz 1988).

The effects of frequency-dependence in sexual selection should generate a dynamic equilibrium among all-female strains preventing extinction of rare clones of all-females, favouring newly arrived clonal forms, and promoting coexistence of multiple clones (Keegan-Rogers \& Schultz 1988).

Results obtained in laboratory from Poeciliopsis lucida and it sperm-dependent all-female biotypes $(P$. monacha-lucida) suggested that the rarefemale advantage operates in the reproductive complex of Poeciliopsis and that such sexual behaviour regulates community structure (Schultz, 1982; Keegan-Rogers \& Schultz, 1988). However, the results from field collection from El Cajon, Mexico pointed out as a natural test of this hypothesis (Schultz, 1982) was inappropriate to test the rare-female advantage hypothesis.

Some all-female biotype strains could not be separated from each other. Strains of $P$. monachalucida (ML) analysed by Schultz (1982) had to be lumped together because at El Cajon they can be identified only by tissue graft analyses (Angus \& Schultz, 1979; Angus \& Schultz, 1979). Moreover, the results reported by Schultz (1982) diverged for the relation between frequency of females and their mating success within the two populations collected.
The mating success of $P$. monacha females was also affected by the rare-female sexual selection. Thus, reproductive success of both sexual and allfemales of $P$. monacha reproductive complex may primarily depend on fecundity and on the probability of acquiring sperm. Therefore, allfemales could replace a coexistent sexual population because it must bear the cost of producing males. Although a numerical dominance of $P$. monacha females over all-female biotypes suggested that reproductive success of sexual females seems to be related to factors other than sexual selection.

Thus, rare-female advantage may promote a diversity of all-female biotypes in the P. monacha reproductive complex. However, rare-female advantage cannot explain coexistence between sexual and all-female biotypes because females of $P$. monacha were also involved in such type of sexual selection. Perhaps a fixed percentage of allfemale biotype is maintained at each location as a consequence of two components. First, the sexual selection that favours rare female phenotypes. Second, by the competition that reduces the abundance of the less adapted phenotypes. However such mechanism is not necessarily involved in $P$. lucida reproductive complex because males seems to prefer their conspecific as mate (Mckay, 19971; Moore \& Mckay, 1971).

Thus, the combination between resource availability and niche partitioning appear to be the principal factor that regulates the abundance of $P$. monacha species and its coexistence with allfemale biotypes (Moore 1984; Vrijenhoek 1979; Vrijenhoek 1984a; Vrijenhoek 1984b; Vrijenhoek 1993).

Resource partitioning has been advanced to account for coexistence among sexual species and all-female biotypes in reproductive complex of the genus Poeciliopsis and Poecilia (Balzano et al., 1989). Although a variety sexual behaviours seems to be important to produce different forms of coexistence and a variety competition strategies within each reproductive complex.

Several examples have been shown how sexual behaviour displayed by both male and female are different among distinct reproductive complexes. The results of the present study strongly suggested that rare-females advantage operated in $P$. monacha reproductive complex. Males of this species might not be as good as $P$. lucida males in discriminating between all-female biotypes and conspecific females. Male dominance hierarchies 
observed in $P$. lucida reproductive consequence of two components. First, the sexual selection that favours rare female phenotypes. Second, by the competition that reduces the abundance of the less adapted phenotypes. However such mechanism is not necessarily involved in $P$. lucida reproductive complex because males seems to prefer their conspecific as mate (Mckay, 19971; Moore \& Mckay, 1971).

Thus, the combination between resource availability and niche partitioning appear to be the principal factor that regulates the abundance of $P$. monacha species and its coexistence with allfemale biotypes (Moore 1984; Vrijenhoek 1979; Vrijenhoek 1984a; Vrijenhoek 1984b; Vrijenhoek 1993).

Resource partitioning has been advanced to account for coexistence among sexual species and all-female biotypes in reproductive complex of the genus Poeciliopsis and Poecilia (Balzano et al., 1989). Although a variety sexual behaviours seems to be important to produce different forms of coexistence and a variety competition strategies within each reproductive complex.

Several examples have been shown how sexual behaviour displayed by both male and female are different among distinct reproductive complexes. The results of the present study strongly suggested that rare-females advantage operated in $P$. monacha reproductive complex. Males of this species might not be as good as $P$. lucida males in discriminating between all-female biotypes and conspecific females. Male dominance hierarchies observed in $P$. lucida reproductive complex restrict assess of subordinate males to conspecific females, promoting an equilibrium dynamic among all-females (Mckay, 19971; Moore \& Mckay, 1971).

Males of $P$. lucida typically approach females with a series of snout-genital contacts, a form of behaviour that might have to do with species identification (Kennett, 1979). The ability of allfemale specimens to mimic the genital patterns of $P$. lucida females appears to be an important mechanism to compete for sperm (Lima et al., 1996).

Female mate competition can be as important as male choice within reproductive complexes. Active female mate choice seems to be involved in some reproductive complexes. For example, female agonistic behaviour against other females and even against males seems also involved in sexual behaviour in $P$. lucida as well as in $P$. mexicana reproductive complexes (Keegan-Rogers \& Schultz 1988, Balsano et al. 1985, Schlupp et al. 1991). P. latipinna females compete for sperm swimming between $P$. formosa and male $P$. latipinna males. Agonistic behaviour such as butting, biting and chasing from $P$. latipinna females against $P$. formosa increased in the absence of $P$. latipinna males (Foran \& Ryan 1994).

Females of $P$. latipinna are also able to copy mate choice behaviour of all-females of $P$. formosa (SCHLUPP et al. 1994). Such intriguing sexual behaviour is another mode of female mate choice that might explain why the energy and time invested in all-females of Poecilia might not be a total loss for males. Theoretically, males that engage with heterospecific females increase their mating success with conspecific females. However this kind of advantage might not be gained by Poeciliopsis males, because besides agonistic behaviour active mate choice seems not to be involved by $P$. lucida or by $P$. monacha females (Mckay, 1971, Moore \& Mckay, 1971, Keegan-Rogers \& Schultz 1988).

In conclusion, rare-female advantage might be responsible for the coexistence among members of $P$. monacha complex and seems to regulate population densities. Because mating success of $P$. monacha females were affected by such sexual behaviour strategy the partitioning of resources might to be the major process that accounts for the maintenance of coexistence among all-female biotypes P.2 monacha-lucida and their sexual host. Sexual behaviour of males and females should differently affect the social structure and the mechanisms responsible for coexistence in reproductive complexes. Identification of payoff for males and females is fundamental to understanding the evolution of reproductive modes within members of reproductive complexes to verify how sexual selection affected all-female biotypes. Comparative studies of secondary sexual characteristics and sexual behaviour strategies would be valuable for a comprehensive picture of similarity and differences among reproductive complexes of Poeciliidae.

\section{RESUMO}

Uma diversidade de fêmeas unissexuadas do gênero Poeciliopsis coexiste com seus ancestrais sexuados em riachos do oeste mexicano. Fêmeas 
unissexuadas são híbridos que dependem do esperma da espécie parental paternal para se reproduzir. Várias hipóteses, incluindo a vantagem da fêmea rara, procuram explicar como a diversidade do biótipos unissexuados é mantida nos complexos reprodutivos de Poeciliopsis. A hipótese propõem que os biótipos unissexuados menos frequentes tenham vantagem de cruzamento sobre os biótipos mais frequentes e que existe um equilíbrio dinâmico regulando tal processo. No complexo reprodutivo de $\mathrm{P}$. monacha localizado no Arroyo de los Platanos, a densidade de dois biótipos unissexuados (P. 2monacha-lucida I e II) variam entre as piscinas formadas. O objetivo do presente estudo foi analisar a fecundidade e o sucesso de cruzamento das fêmea deste riacho para testar a hipótese. $\mathrm{O}$ sucesso de cruzamento das fêmeas foi inversamente correlacionado a sua densidade, dando suporte a hipótese levantada.

\section{ACKNOWLEDGMENTS}

We express our deepest gratitude to Robert C. Vrijenhoek who provided the strains to developed the analysis, to Richard Trout and Carol J. Kobak for their suggestions on statistical analyses. NRW Lima also gratefully acknowledge fellowship support from the Conselho Nacional de Pesquisa (CNPq-PROC. 352085/96-7).

\section{REFERENCES}

Anderson, R. M. and May, R. M. (1985), Epidemiology and genetics in the coevolution of parasites and hosts. Proc. R. Soc. London Ser. B., 219, 281-283.

Angus, R. A. and Schultz, R. J. (1978), Variation and clonal structure in a unisexual fish. Amer. Natur., 112, 41-55.

Angus, R. A. and Schultz, R. J. (1979), Clonal diversity in the unisexual fish Poeciliopsis monacha-lucida: A tissue graft analysis. Evolution, 33, 27-40.

Balsano, J. S.; Kurcharski, K.; Randle, E. J.; Rash, E. M. and Monaco, P. J. (1981), Reduction of competition between unisexual and bisexual females of Poecilia in northeastern Mexico. Environ. Biol. Fish., 6, 39-48.

Balsano, J. S.; Rasch, E. M. and Mônaco, P. J. (1989), The evolutionary ecology of Poecilia formosa and its triploid associate, pp. 277-297. In - Ecology and evolution of poeciliid fishes (Poeciliidae) Meffe, G. A. and Snelson Jr., F. F. (eds.). Prentice Hall, Englewood Cliffs, New Jersey.
Balsano, J. S.; Randle, E. J.; Rash, E. M. and Monaco, P. J. (1985), Reproductive behavior and the maintenance of all-female Poecilia. Environ. Biol. Fish., 12, 251-163.

Cimino, M. C. (1972a), Meiosis in triploid all-female fish (Poeciliopsis, Poeciliidae). Science, 175, 1484-1486.

Cimino, M. C. (1972b), Egg production, polyploidization and evolution in a diploid all-female fish of the genus Poeciliopsis. Evolution, 26, 294-306.

Foran, C. M. and Ryan, M. J. (1994), Female-female competition in a unisexual/bisexual complex of mollies. Copeia, 504-508.

Fryer, S. E.; Oswald, R. C.; Probert, A. J. and Runham, N. W. (1990), The effect of Schistoma haematobium infection on the growth and fecundity of three sympatric species of bulinid snails. J. Parasit., 76, 557-563.

Keegan-Rogers, V. and Schultz, R. J. (1988), Sexual selection among clones of unisexual fish (Poeciliopsis, Poeciliidae): genetic factors and rarefemale advantage. Amer. Natur., 132, 846-868.

Kennett, C. B. (1979), Aspects of mating behavior and selection in Poeciliopsis population complexes (Pisces: Poeciliidae). PhD. Fordham University. $187 \mathrm{pp}$.

Lima, N. R. W.; Kolback, C. J. and Vrijenhoek, R. C. (1996), Evolution of sexual mimicry in spermdependent clonal forms of Poeciliopsis (Pisces: Poeciliidae). J. Evol. Biol., 9, 185-203.

Lima, N. R. W. and Vrijenhoek, R. C (1996), Avoidance of filial cannibalism by sexual and clonal forms of Poeciliopsis (Pisces: Poeciliidae). An. Beh., 51, 293-301.

Lima, N. R. W. (1998), Genetic analysis of predatory efficiency in natural and laboratory made hybrids of Poeciliopsis (Pisces: Poeciliidae). Behaviour., 135, 83-98.

Lively, C. M.; Craddock, C. and Vrijenhoek, R. C. (1990), The red queen hypothesis supported by parasitism in sexual and clonal fish. Nature, 344, 864-866.

Leslie, J. F. (1982), Linkage analysis of seventeen loci in the poeciliid fish (genus Poeciliopsis). J. Hered., 73, 19-23.

Mckay, F. E. (1971), Behavioral aspects of population dynamics in unisexual-bisexual Poeciliopsis (Pisces: Poeciliidae). Ecology, 52, 778-790.

Minchella, D. J. and Loverde, P. T. (1981), A cost of increased early reproductive effort in the snail. Biomphalaria glabata. Am. Natur., 118, 876-881.

Minchella, D. J. (1985), Host life-history variation in response to parasitism. Parasitology, 90, 205-216.

Moore, W. S. and Mckay, F. E. (1971), Coexistence in unisexual-bisexual species complexes of Poeciliopsis (Pisces: Poeciliidae). Ecology, 52, 791-799.

Moore, W. S. (1976), Components of fitness in the unisexual fish Poeciliopsis monacha-occidentalis. Evolution, 30, 564-578. 
Moore, W. S. (1984), Evolutionary ecology of unisexual fishes. In - Evolutionary genetics of fishes. Turner, B. J. (ed.). Plenum Press, New York. pp. 329-398.

Mugglenton, J. (1979), Non-Random mating in wild populations of polymorphic Adalia bipunctata. Hereditary, 41, 57-65.

O'donald, P. and Muggleton, J. (1979), Melanic polymorphism in ladybird maintained by sexual selection. Heredity, 143-148.

Quattro, J. M. and Vrijenhoek, R. C. (1989), Fitness differences among remnant populations of the Sonoran topminnow, Poeciliopsis occidentalis. Science, 245, 976-978.

Quattro, J. M and Weeks, S. C. (1991), Correlation of egg size and energetic content in sexual and clonal biotypes of Poeciliopsis. J. Fish Biol., 38, 331-334.

SAS (1985), SAS User's Guide: Statistics, Version 5 Edition. Cary, NC, SAS Institute.

Schenck, R. A. and Vrijenhoek, R.C. (1986), Spatial And Temporal Factors Affecting coexistence among sexual and clonal forms of Poeciliopsis. Evolution, 40, 1060-1070.

Schenck, R. A. and Vrijenhoek, R. C. (1989), Coexistence among sexual and asexual forms of Poeciliopsis: Foraging behavior and microhabitat selection. In - Evolution and ecology of unisexual vertebrates. Dawley, R. M. and Bogart, J. P. (eds.). New York State Museum Bulletin. Bulletin 466. Albany, New York. USA. pp. 39-48.

Schlupp, I.; Parzefall, J. and Schartly, M. (19--), Male mate choice in mixed bisexual/unisexual breeding complexes of Poecilia (Teleostei: Poeciliidae). Ethology, 88, 215-222.

Schlupp, I.; Marler, C. and Ryan, M. J. (1994), Benefit to male sailfin mollies of mating with heteroespecific females. Science, 263, 373-374.

Schultz, R. J. (1967), Gynogenesis and triploidy in the viviparous fish Poeciliopsis. Science, 157, 1564-1567.

Schultz, R. J. (1969), Hybridization, unisexuality and polyploidy in the teleost Poeciliopsis (Poeciliidae) and other vertebrates. Amer. Natur., 103, 605-619.

Schultz, R. J. (1982), Competition and adaptation among diploid and polyploid clones of unisexual fishes. In: Evolution and genetics of life histories. Dingle, H. and Hegmann, J. P. (eds.). SpringerVerlag, Berlin. Germany. pp. 103-119.

-Schultz, R. J. (1989), Origins and relationships of unisexual poeciliids. In - Ecology and evolution of poeciliid fishes (Poeciliidae). Meffe, G. A. and Snelson Jr., F. F. (eds.). Prentice Hall, Englewood Cliffs, New Jersey. pp. 69-86.

Stenseth, N. C.; Kirkendall, L. R. and Moran, N. (1985), On the evolution of pseudogamy. Evolution, 39, 294-307.
Thibault, R. E. and Schultz, R. J. (1978), Reproductive adaptations among viviparous fishes (Cyprinodontiformes : Poeciliidae). Evolution, 32, 320-333.

Turner, C. L. (1937), Reproductive cycle and superfetation in poeciliid fishes. Biol. Bull., 72, 145-164.

Vrijenhoek., R. C. (1979), Factors affecting clonal diversity and coexistence. Am. Zool., 19, 787-797.

Vrijenhoek., R. C. (1984a), Ecological differentiation among clones: the frozen niche variation model. In Population biology and evolution. Wohrmann, K. and Loeschcke, V. Springer-Verlag, Heidelberg, Berlin, Germany. pp.217-231.

Vrijenhoek., R. C. (1984b), The evolution of clonal diversity in Poeciliopsis. In - Evolutionary genetics of fishes. Turner, B. J. (ed.). Plenum Press, New York. pp. 399-429.

Vrijenhoek., R. C. (1993), The origin and evolution of clones versus the maintenance of sex in Poeciliopsis. J. J. Hered., 84, 388-395.

Vrijenhoek, R. C.; Dawley, R. M.; Cole, C. J. and Bogart, J. P. (1989), A list of known unisexual vertebrates. In - Evolution and ecology of unisexual vertebrates. Dawley, R. M. and Bogart, J. P. (eds.). New York State Museum Bulletin. Bulletin 466. Albany, New York. USA. pp. 19-23.

Vrijenhoek., R. C.; Pfeiler, E. P. and Wetherington, J. D. (1992), Balancing selection in a desert streamdwelling fish, Poeciliopsis manacha. Evolution, 46, 1642-1657.

Weeks, S. C.; Gaggiotti, O. E.; Spindler, K. P. and Vrijenhoek, R. C. (1992), Feeding behavior in sexual and clonal strains of Poeciliopsis. Behav. Ecol. Sociobiol., 30, 1-6.

Weeks, S. C. (1996), A reevaluation of the Reed Queen model for the maintenance of Sex in clonal-sexual fish complex (Poecillidae: Poeciliopsis). Can. Jour. Fish. Aqua. Sci., 53, 1157-1164.

Received: June 19, 2000; Revised: November 07, 2000; Accepted: August 28, 2001. 